\title{
In reply: Comment on women anesthesiologists' journeys to academic leadership
}

\author{
Gianni R. Lorello, BSc, MD, MSc (Med Ed), CIP, FRCPC (1) - Alana M. Flexman, MD, \\ FRCPC
}

Received: 20 August 2020/Accepted: 20 August 2020/Published online: 9 September 2020

(c) Canadian Anesthesiologists' Society 2020

\section{To the Editor,}

We thank Aggarwal et al. ${ }^{1}$ for their interest in our constructivist grounded theory-inspired study looking at better understanding women anesthesiologists' journeys to academic leadership. ${ }^{2}$ We agree that a fundamental cultural shift and epistemic shift within anesthesiology needs to occur to dismantle dominant ideologies and to be more inclusive of all voices. Medical education exists as a subculture within academic medicine and serves to indoctrinate trainees into these common positions, beliefs, and values-i.e., how one comes to know, what one is able to know, and methods of knowledge generation. ${ }^{3}$ Culture can be viewed in a number of ways, two of which we detail herein. The first perspective views culture as an outcome, based on a set of patterns that direct our behaviours and experiences-e.g., customs, traditions, and habits. ${ }^{4}$ The

This reply letter is related to letter 20-00857.

G. R. Lorello, BSc, MD, MSc (Med Ed), CIP, FRCPC ( $\square)$.

University Health Network, Toronto Western Hospital -

Department of Anesthesia and Pain Medicine, Toronto, ON, Canada

e-mail: Gianni.Lorello@uhn.ca

Department of Anesthesiology and Pain Medicine, The University of Toronto, Toronto, ON, Canada

The Wilson Centre, Toronto, ON, Canada

Women's College Research Institute, Toronto, ON, Canada

\author{
A. M. Flexman, MD, FRCPC \\ Vancouver General Hospital - Department of Anesthesiology, \\ Vancouver, BC, Canada
}

Department of Anesthesiology, Pharmacology and Therapeutics, The University of British Columbia, Vancouver, BC, Canada alternative lens views culture as the source of learned behaviours and as a separate epistemic culture. ${ }^{4}$ Trainees do not serendipitously encounter this phenomenon but are rather socialized into this culture. Trainees' experiences are therefore influenced by social phenomena that are constructed, sustained by observation, and, through emulative learning, are entrenched and perpetuated in the medical profession.

"A way of seeing is a way of not seeing." Medical culture needs to embrace the multiple ways of seeing and knowing to be more inclusive and to support women and under-represented groups into leadership positions. Multiple aspects of current culture need to be examined, and both a top-down and a bottom-up approach is needed to dismantle embedded systems of discrimination, as well as to create safe and inclusive environments. Understanding unconscious bias is a critical component of this process, as is conscious mentorship and sponsorship. Leaders need to endorse and support speaking up against microaggressions and discriminatory acts, empowering bystanders at all levels, and ensuring there is accountability in place. ${ }^{6}$ Changing culture is complex, slow, and rarely straightforward. We thank Aggarwal et al. ${ }^{1}$ for highlighting the urgent need for today's leaders to embrace and drive this cultural and epistemic shift towards greater inclusion.

\section{Disclosures None.}

Funding statement None.

Editorial responsibility This submission was handled by Dr. Hilary P. Grocott, Editor-in-Chief, Canadian Journal of Anesthesia. 


\section{References}

1. Aggarwal A, Silver JK, Kowalski AM. Comment on women anesthesiologists' journeys to academic leadership. Can J Anesth 2020; DOI: https://doi.org/10.1007/s12630-020-01802-5.

2. Lorello GR, Cil T, Flexman AM. Women anesthesiologists' journeys to academic leadership: a constructivist grounded theory-inspired study. Can J Anesth 2020; 67: 1130-9.

3. Cetina KK. Epistemic Cultures. How the Sciences Make Knowledge: Harvard University Press; 2009.

4. Geertz C. The Interpretation Of Cultures. Basic Books; 1973.
5. Burke K. Permanence and Change. Pickle Partners Publishing; 2018.

6. Aysola J, Barg FK, Martinez AB, et al. Perceptions of factors associated with inclusive work and learning environments in health care organizations: a qualitative narrative analysis. JAMA Network Open 2018; DOI: https://doi.org/10.1001/ jamanetworkopen.2018.1003.

Publisher's Note Springer Nature remains neutral with regard to jurisdictional claims in published maps and institutional affiliations. 